\title{
Newborns, Infants, and Adolescents in Postmedieval Northern Finland: A Case Study from Keminmaa
}

\author{
Sanna Lipkin (1) - Sirpa Niinimäki • Saara Tuovinen • \\ Heli Maijanen • Erika Ruhl • Jaakko Niinimäki • \\ Juho-Antti Junno
}

Accepted: 10 July 2019 /Published online: 10 November 2020

(C) The Author(s) 2020
S. Lipkin $(\bowtie) \cdot$ S. Niinimäki $\cdot$ S. Tuovinen $\cdot$ H. Maijanen Archaeology, Pentti Kaiteran katu 1, Linnanmaa, PO Box 8000, FI-90014 University of Oulu, Oulu, Finland

e-mail: sanna.lipkin@oulu.fi

E. Ruhl

Department of Anthropology, State University of New York at Buffalo, 380 Fillmore Academic Center, Ellicott Complex, Buffalo, NY 14261, U.S.A.

J. Niinimäki

Department of Radiology, Pentti Kaiteran katu 1, Linnanmaa, PL 5000, FI-90029 Oulu University Hospital, Oulu, Finland

\section{J.-A. Junno}

Department of Anatomy, Faculty of Medicine Archaeology, Medical Research Center Oulu Oulu University Hospital, FI-90014 University of Oulu, Pentti Kaiteran katu 1, Linnanmaa, PO Box 8000, Oulu, Finland
Extracto Se examinaron cuatro ataúdes que datan del período comprendido entre mediados del siglo XVIII y mediados del siglo XIX en Keminmaa, en el norte de Ostrobotnia, Finlandia, mediante tomografía computarizada (TC), una metodología con aplicaciones de investigación para explorar restos humanos, ataúdes y textiles funerarios. Se estimó la edad y, en dos casos, el sexo de los restos, y tanto las fuentes históricas como el material arqueológico sugieren que la socialización a través del género fue evidente en esta colección. Este artículo explora tanto el testimonio material acerca del cuidado, dedicación e inocencia de los entierros de recién nacidos y bebés, así como el proceso de socialización y el papel de las adolescentes en proveer materiales funerarios para los niños.

Résumé Quatre cercueils datant de la période entre la moitié du 18ème siècle et la moitié du 19ème siècle découverts à Keminmaa dans l'Ostrobotnie du nord la Finlande ont fait l'objet d'une étude en recourant à la tomodensitométrie $(\mathrm{CT})$, une méthodologie associée à des applications de recherche pour l'étude des restes humains, des cercueils et des tissus funéraires. L'âge et dans deux cas, le sexe des restes ont pu être estimés et les sources historiques comme le matériel archéologique suggèrent que la socialisation par le biais du genre était apparente dans ces éléments recueillis. Cet article s'intéresse au témoignage matériel des soins, du dévouement et de l'innocence des enterrements de nouveau-nés et d'enfants, ainsi qu'au processus de socialisation et au rôle des femmes adolescentes dans la fourniture des articles funéraires pour les enfants. 
Keywords infants in archaeology - socialization - funerary archaeology - computed-tomography scanning

\section{Introduction}

This article considers the material dimensions of gender, infancy, and adolescence during the late 18th and early 19th centuries in northern Ostrobothnia, Finland (Fig. 1). About 100 child burials dating between the late 17th century and mid-19th century have been recorded in northern Ostrobothnia, the majority of which are infants. Due to cold and dry winters, a portion of this collection has partly mummified and contains uncommonly wellpreserved textiles. Together with contemporary written sources, the collection provides a unique opportunity to discuss infancy, adolescence, and the shift into adulthood within the community. The collection also offers the chance to discuss aspects of child-specific socialization and, in particular, cultural conceptions of the intersection of age, gender, family status, and the innocence of childhood. The material for the case study consists of infant burials, which include coffins, human remains, and clothing recovered from under the floor at St. Michael's
Church at Keminmaa. Four of these burials were intensively examined using computer-tomography (CT) scans. Based on historical sources and the clothes of the deceased, these coffins date between the mid-18th century and the mid-19th century. This article evaluates the ways in which infants at Keminmaa were buried and how their burials reflect their status in the community. At Keminmaa, a total of 60 burials were inventoried (44 children, 16 adults). Of these, 25 were inaccessible either due to limited space below the church's wooden floor or because the coffin lids were sealed with nails. It was not considered essential to break the iron nails and open the sealed coffins. The remaining 36 coffins were examined through the broken coffin lids by opening lids that were partially open or through CT scanning. Inside these 36 coffins, 14 human remains were found skeletonized (10 children, 4 adults), no human remains were recorded inside 3 coffins ( 1 adult-sized coffin, 2 child-sized coffins), and 19 remains were naturally mummified (15 children, 4 adults). Funerary attire was predominantly well-preserved, even in the burials with skeletonized remains.

This archaeological burial material also offers the opportunity to identify and reconstruct historically
Fig. 1 Map showing the locations of the data sources in northern Ostrobothnia. (Image by K. Vajanto, 2018.)
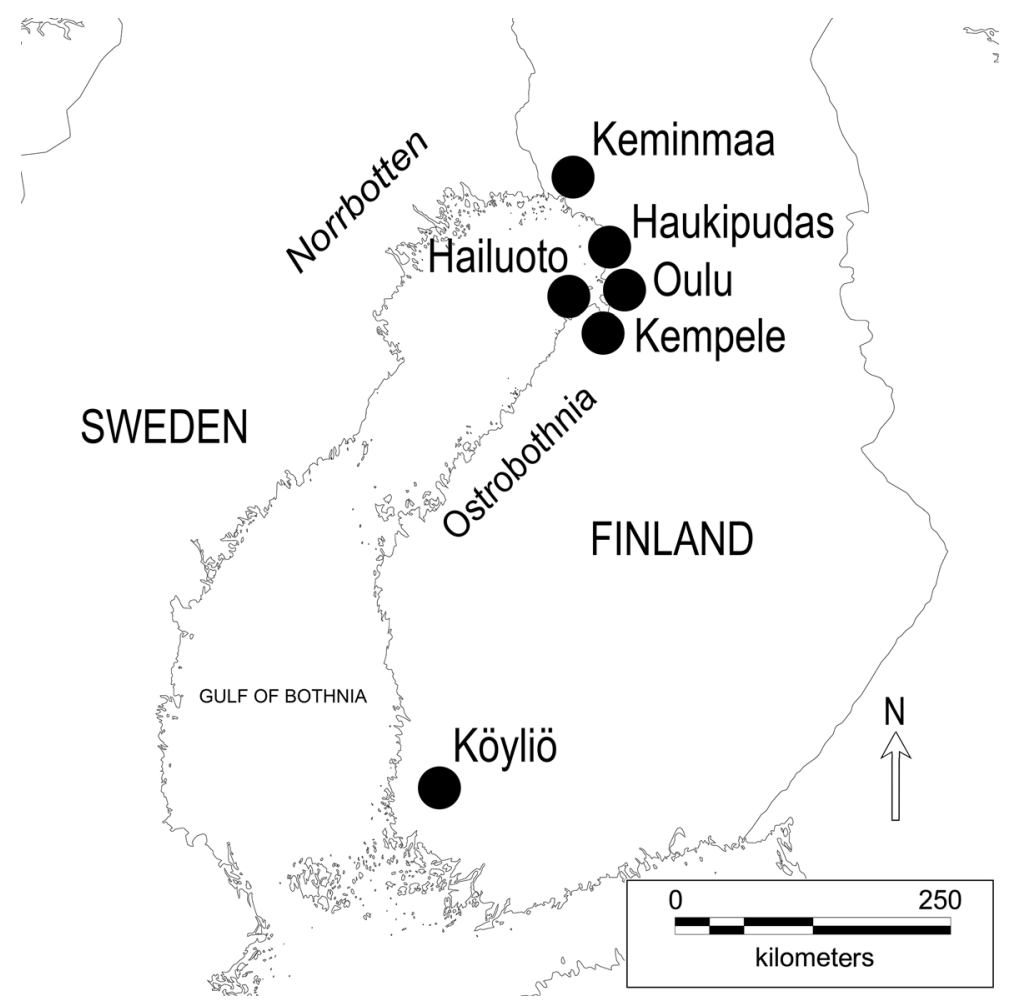
specific cultural constructions of infant gender in the past, as the sex of some infant remains can be identified from the soft tissues by CT scanning. This would be impossible in most archaeological contexts, as sex cannot be reliably determined from skeletal remains until after puberty. This study approaches gender as an expression of both social structure and practice, distinct from purely biological definitions of sex.

This article will juxtapose two extremes of childhood: on one side, the very young, and, on the other side, those progressing through adolescence. Sara Wacklin's book, One Hundred Memories from Ostrobothnia, suggests that the youth of Ostrobothnia were responsible for providing clothing for young children's burials (Wacklin 1844:2,21). This means that they furnished the coffin, chose and cut the fabrics to dress the child, and prepared the accessories. Wacklin was born in northern Ostrobothnia's principal town, Oulu, and discussed both infants/young children and adolescents in her memoirs based on her own childhood experiences and her experiences as a schoolteacher, which provides a starting point from which to evaluate infant-burial practices. This article considers the cultural construction of both infancy and adolescence, as well as the relationship between these two age groups as they are represented in the material culture, funerary clothing, and accessories present in archaeological burials. While child burials are generally interpreted as a reflection of adult perceptions of children's identities vis-à-vis age, gender, and cultural or ethnic background, Wacklin $(1844: 2,21)$ suggests that the youth may have played a potentially significant role in producing funerary assemblages. Their participation in funeral preparation socialized older adolescents to gendered subjectivities and parental social roles (Lillehammer 2010:13). Through an interpretation of the socialization processes visible in the infant burials, adolescents are discussed in this article as producers and reinforcers of the socialization process. Examining the infants' burials and the choices made while constructing them through the study of the northern Ostrobothnian archaeological materials illuminates youths' perception of dead infants and early child deaths.

\section{History of Finland as Part of Sweden and Russia}

The modern nation of Finland was part of Sweden until 1809 , after which the country became an autonomous part of the Russian Empire, known as the Grand Duchy of Finland. During Swedish rule, Finland was a province of the nation, but it was simultaneously the subject of unifying policies, particularly from the 17 th century onwards. The effort was to integrate Finland into Swedish culture while the province was being exploited materially. Life in Finland was unsettled, particularly along the eastern border, due to Russian interest in the territory. Finland was occupied by Russia between 1713 and 1721 during the "Great Hatred," and in 1742-1743 during the Russo-Swedish War. In many ways, Finland was a meeting point of Eastern and Western influences by the 18th century: the Roman Catholic Chuch and, post-Reformation, the Lutheran Church functioned side by side with the Greek Catholic Orthodox Church; in return for Finland's export products (tar, lumber, butter, and meat), ships imported salt, grains, wines, textiles, and other sumptuary goods from Europe; during certain time periods, due to mercantilism and trade embargos, Karelian tradesmen served as an important medium for importing goods, especially to northern Finland, from central Europe, England, and Karelia through Archangel via the Arctic Ocean (Halila 1953:211-212; Mäntylä 1997:204,250,290-295,356; Lehtinen and Sihvo 2005:23-29). The shift to Russian rule changed the laws and administrative structure, but was greeted mostly without resistance (Junnila 1987:11-12). Finland gained increasing autonomy over the 19th century, developed an idealistic nationalist movement during the late 19th century, and secured independence in 1917.

\section{Perception of Newborns and Infants in Postmedieval Finland}

To interpret the funerary remains, it is important to understand the common conceptions of childhood during the late 18th and early 19th centuries. Due to a combination of poor health care and nutritional practices, child mortality was high in Finland until the end of the 19th century, with approximately $40 \%$ of children dead before the age of four (Turpeinen 1979:107-111). It is likely that most women experienced miscarriages and infant or child loss at some time in their lives (Becker 2004:264). During the postmedieval period, survival for newborns less than one-month old would have been lower than today, and it is unlikely that prematurely born infants younger than the range of a normal pregnancy (37 to 42 weeks) would have survived. High child mortality and the common experience 
of losing a child impacted contemporary perceptions of infancy, children's social roles, upbringing, education, and burial customs. Children were treated differently from adults after death, as seen through children's shorter wake periods, approximately one week, in contrast to an average two to three weeks for adults (Oulun makunta-arkisto [OMA] 1758-1812, 1779-1814). The general conception of childhood is reflected both in the historical sources and archaeological funerary materials, specifically in the treatment of newborns and infants. Archaeological material also indicates that children's burials were distinct from those of adults. Children were buried with floral accessories, textiles embroidered with silver thread, and caps decorated with laces, which occur only occasionally in adult burials. Children's funerary attire differs from adult attire in the absence of leather gloves, even though they are common in adult burials.

The concept of status as a full member of the community likely shaped emotions toward deceased children and the ritual of preparing children for burial. Christening was a ritual that made a person part of the community, and unbaptized infants were not considered full members of society and could not be buried in the same manner as a baptized child. During the 17 th century there was no uniform treatment for the burial of unbaptized infants, and individual bishops and priests generally determined how they were buried in their respective parishes. For that reason, the funeral ritual was not always granted to unbaptized infants during the 17 th and 18th centuries. The practices for burying these infants varied: some unbaptized newborns were interred during silent ceremonies with a minimum of prayers, while others received full funerals. After the late 17 th century, infants were officially allowed to be buried in the churchyard, albeit quietly and with a minimum of ceremonies (prayers and a blessing). The exchange of letters between priests and their parishioners and priests and their bishops concerning stillborn- and newbornburial practices indicates that infants' roles in the community were under debate (Rimpiläinen 1971:268-275; Itkonen 2012:13-15).

Distinctive attitudes toward stillborn infants are also evident in northern Ostrobothnian parish records between the late 18 th century and the early 19 th century. It appears that individual parish vicars had a habit of drawing a "sad face" or "skull" next to nearly every stillborn infant born in the parish (Fig. 2). This practice is observable in the records of the parish of Hailuoto for every stillborn child between 1758 and 1781 (OMA
1758-1812), Kempele for the majority of stillborn children from 1781 to 1824 (OMA 1751-1802; 18031866), and Tervola inconsistently between 1784 and 1795 (OMA 1779-1814). It is possible that these stillborn infants were recorded with faces/skulls because they were not baptized. It appears that the skull symbol is also connected to peculiar deaths. For example, a skull was placed next to the name of a six-year-old child who was murdered at Hailuoto in 1768 , as well as by the name of her female murderer, who, due to the severe nature of her crime, was sentenced to execution by throat cutting and then burning at the stake (OMA 1758-1812).

In addition to debate over burial practices regarding unbaptized newborns, breastfeeding practices were also under discussion during the 18th century. The officials noted the link between infant deaths and the lack of breastfeeding. In fact, between 1749 and 1763 the governors of Ostrobothnia and Norrbotten (the Swedish side of the Gulf of Bothnia) repeatedly complained about how mothers were not breastfeeding their infants, as well as the lack of skillful midwives. Unfortunately, some mothers in rural communities fed their children with cow's milk left above the cradle in an unhygienic horn while they worked the fields during the day. The resulting spoiled milk made children sick and contributed to infant mortality. Ostrobothnian governor Gustaf Piper unsuccessfully attempted to enact a law that would fine mothers who did not breastfeed and whose infants died before the age of six months (Halila 1954:639640). There were no educated midwives in northern Finland until 1762, when Anna Snellman arrived in Oulu, the same year that the first pharmacy was established in the town (Halila 1953:537). Only one doctor served the whole of northern Ostrobothnia (Halila 1954:649; Vainio-Korhonen 2012:247). Eventually, thanks to the developments in medical care beginning in the late 19th century, child mortality gradually decreased (Table 1), which likely changed community understandings of childhood and upbringing.

\section{Role of Female Adolescents in the Preparation of Burial for Children}

The cultural context of infant burials in northern Ostrobothnia is clearly presented in Sara Wacklin's (1844) short story "Likgrannlåterna" (clothing for the deceased). Archaeological evidence in the form of infant 
Fig. 2 "Skull" or "sad face" markings from the Hailuoto church records: (a) two stillborn children from 1771 and $(b)$ a murdered child and her female murderer from 1768 (OMA 1758-1812). (Photo by S. Lipkin, 2018.)
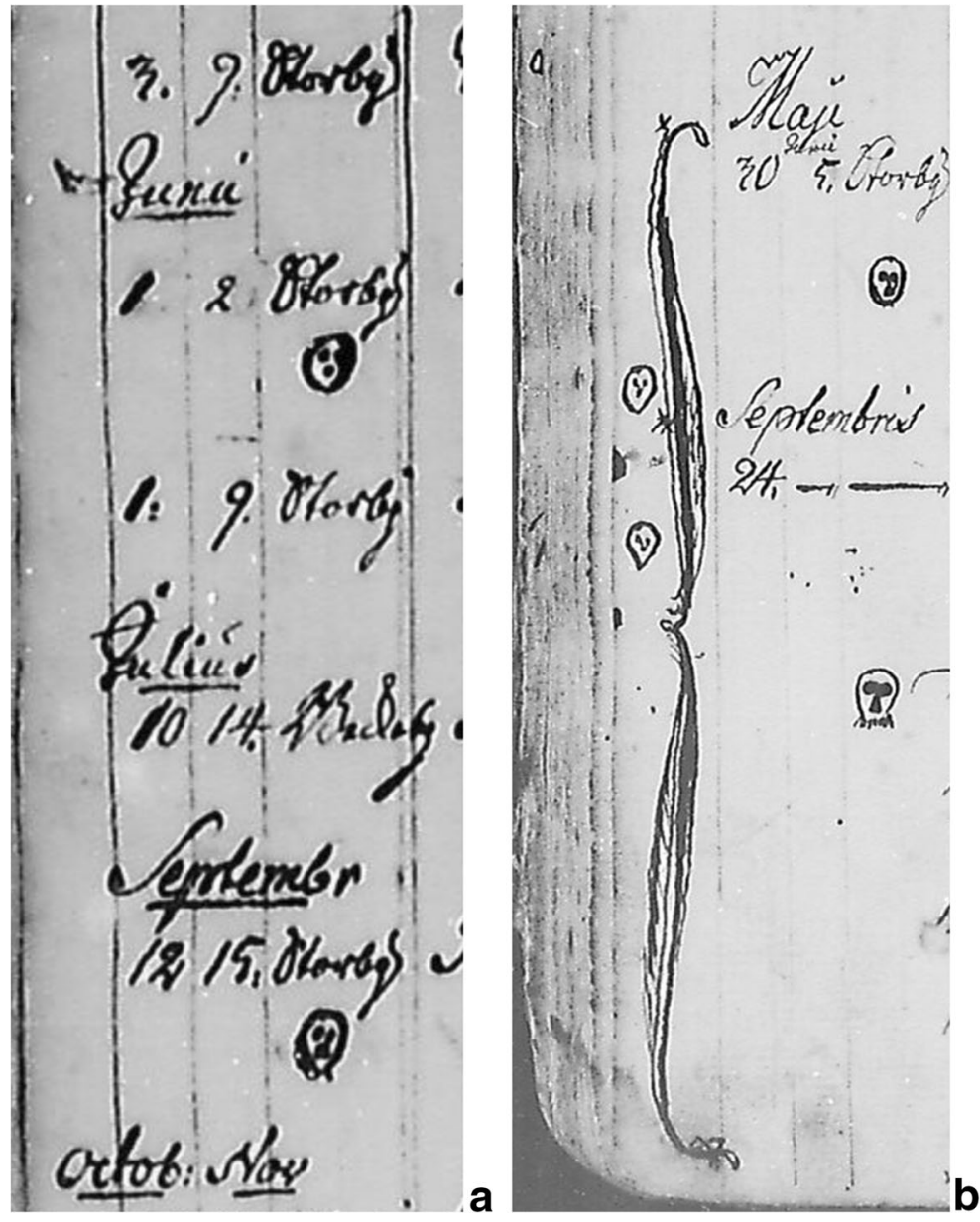

Table 1 Mortality by percentage in Finland 1751-1925

\begin{tabular}{lcccc}
\hline Years & Infant $(\%)$ & $1-2 / 3-4 / 0-4$ Years $(\%)$ & Total Mortality $0-4$ Years $(\%)$ & Total Mortality of the Population (\%) \\
\hline $1751^{\mathrm{a}}-1775$ & 23 & 17 & 40 & 3 \\
$1776-1800$ & 21 & 18 & 39 & 3 \\
$1801-1825^{\mathrm{b}}$ & 20 & 19 & 40 & 3 \\
$1826-1850$ & 19 & 16 & 35 & 2.5 \\
$1851-1875^{\mathrm{b}}$ & 19 & 20 & 28 & 4 \\
$1876-1900$ & 15 & 13 & 19 & 2 \\
$1901-1925^{\mathrm{c}}$ & 11 & 8 & 29
\end{tabular}

Note: After Turpeinen (1979:table 1). Mortality rates 1/1000 have been converted to percentages.

${ }^{a}$ In 1751 the mortality rate for children under four years of age was $33.6 \%$.

${ }^{\mathrm{b}}$ Even though variation between years exists, in general, child mortality declines. Two peak years raise the average mortality of $1801-1825$ and 1851-1875 considerably: in 1808 (during the Finnish war) mortality for children under four years of age was $73.9 \%$, while the total mortality for the population was $6.2 \%$; and in 1868 (documented year of crop failures and famine) mortality for children under four years of age was $81.3 \%$, and the total population mortality was $7.8 \%$.

${ }^{\mathrm{c}}$ In 1925 the mortality rate for children under four years of age was $13.1 \%$. 
and young-child burials exhibits features similar to those described by Wacklin: infants and young children were typically buried wearing white fabrics arranged to resemble fashionable clothing and clouds. Wacklin $(1844: 2,21)$ indicated that infant boys were buried wearing green wreaths on their heads, holding a similar rod of artificial foliage in one hand, and with a wreath on the coffin. In addition to wreaths on their heads and the coffins, girls also received a floral sprig, a silk jacket, and a crown. The child's name was written in gold wire on the pillow above the head. Coffin exteriors were often painted yellow, which Wacklin indicates was "the color of the shriveled leaves."

Wacklin's description of children's burial attire is more accurate for Keminmaa burials than for other burials from the region. This is likely due to the fact that these burials most likely date to the late 18th and mid19th centuries, whereas examples from other church sites are from the mid-18th century or earlier and thus represent earlier traditions. Differences in materials may also be due to local textile supplies and materials families had available for burial. In general, children's funerary attire was similar regardless of the children's social rank. Burial under church floors (Hailuoto, Haukipudas, Keminmaa) was reserved for higherranking individuals, and the so-called ordinary people were buried in the churchyard (Oulu Cathedral). Only slight temporal and locational variation is visible among burials from different contexts according to contemporary clothing fashions and styles of tying floral arrangements.

The funerary preparations, as described by Wacklin $(1844: 2,21)$, were made by the child's virgin godmother, who invited her friends to help her work through the night to prepare the decorations. Wacklin suggests that, while local custom dictated that adolescents should only associate with their own gender, according to old customs the young gentlemen - largely brothers and other relativeswere allowed to attend this occasion, which often became a joyous event. Wacklin remarks that, following such an evening, bridal wreaths were often tied.

As a teacher in a girls' school, Wacklin (1844), throughout her book, described female adolescents and the varied roles they were given. For example, girls who had recently made their confirmations were considered of age to be suitable godmothers, construct clothing for deceased children, and attend balls arranged by both Swedish and Russian officers during the Finnish War of 1808 . The roles indicate that these adolescents were approaching adulthood, but, in the eyes of their own families, especially their mothers, they were still considered children. In Wacklin's story, one mother often shakes her head and comments on the actions of her daughters: "A child is a child" (Wacklin 1844:2,9-10). This highlights the liminality of their existence, both as children in the eyes of their own families and as women in the eyes of society at large. These young women were older than 13 years, as according to the Swedish Church Law of 1686 they were allowed to participate in confirmation classes beginning at the age of 13 or 14 years as soon as they sufficiently understood the catechism and were capable of soul searching. The standing order for confirmation instruction in Finland from 1919 required students to be 15 years old before attending (Seppälä 1998:33,41-42).

\section{Infant Burials in Keminmaa}

Sixty burials from beneath the church of St. Michael in Keminmaa have been inventoried. Of these, 44 are child burials (Fig. 3). Outside the church is an ossuary where skeletonized remains were eventually moved in order to free more space for new coffins. Church construction at Keminmaa began in the 1550s (Hiekkanen 2014:509510), and burials under the church floor started by the early 17 th century, were discontinued for a period in the 1760 s, and resumed after the new church was built nearby in the 1790s. Even though burials inside churches were forbidden in 1822, the custom continued in the old abandoned St. Michael's Church until at least the 1870s (Satokangas 1997:428). Consequently, the preserved burials date predominantly between the mid18 th century and mid-19th century. This dating is supported by evidence from textiles found inside coffins selected for in-depth examination.

Four of the smallest child coffins that were accessible and well-preserved were taken to Oulu University Hospital for CT scanning. Full-body images were acquired with a Somatom Definition Flash dual source CT scanner (Siemens Healthcare, Forchheim, Germany) at $100 \mathrm{kV}$ and $140 \mathrm{kV}$ with an in-plane resolution of 0.68 $\times 0.68 \mathrm{~mm}$ and a slice thickness of $0.5 \mathrm{~mm}$. Dental areas were rescanned with an in-plane resolution of $0.16 \times$ $0.16 \mathrm{~mm}$ and a slice thickness of $0.6 \mathrm{~mm}$. The scans were analyzed using OsiriX MD 64-bit software, Version 7.0. Despite some preservation-related issues (e.g., smaller bones tend to preserve poorly) and biases (e.g., 
Fig. 3 Floor plan of St. Michael's Church at Keminmaa. (Drawing by S. Lipkin, 2017; based on Ojanlatva and Paavola [1997:figure 2].)

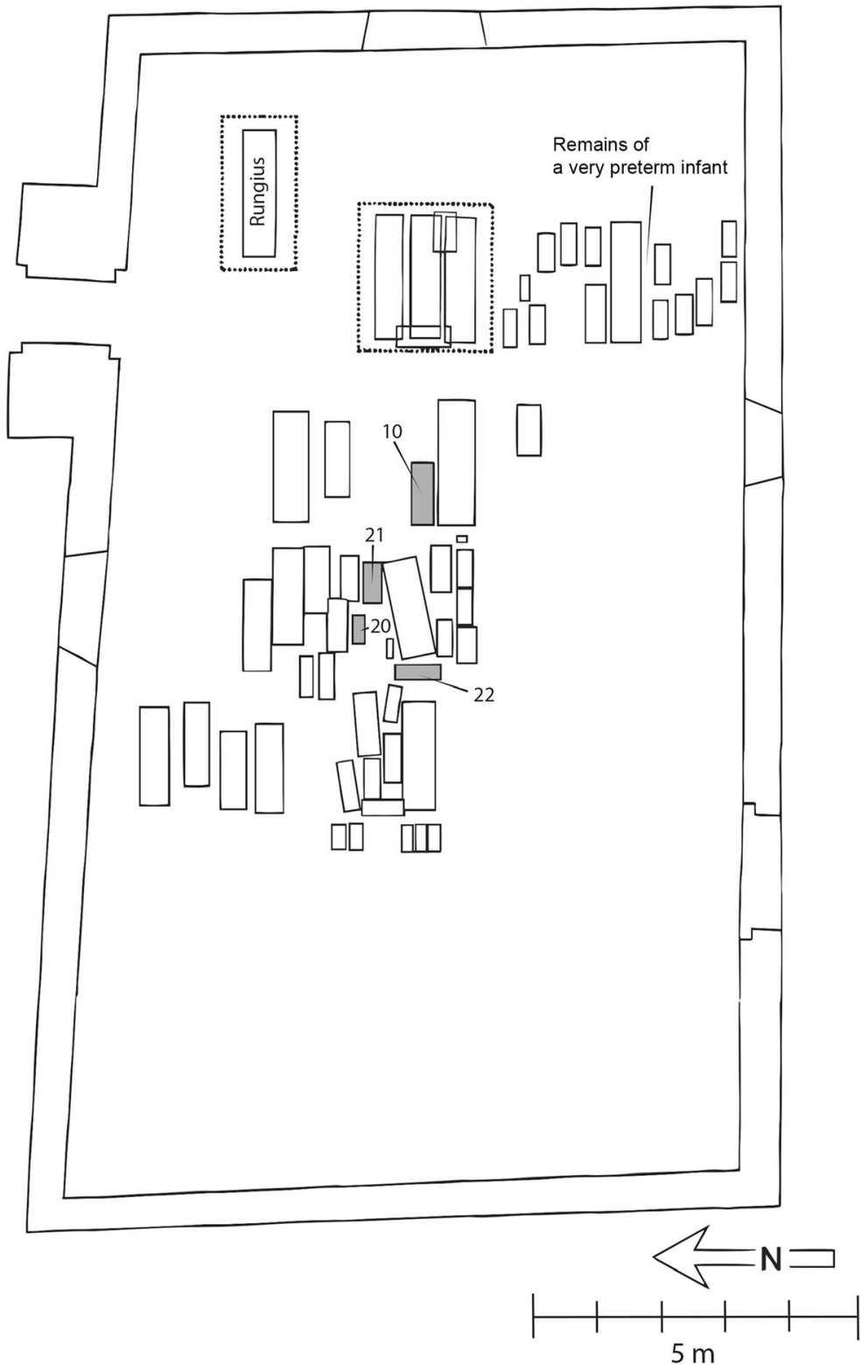

variation in individual development) often encountered in the examination of children's remains in the archaeological record, the excellent preservation of Keminmaa's mummified human remains and the use of CT imaging has enabled a detailed study. The CT scans have made it possible to see inside the coffins without opening the coffin lids in order to document the state of preservation of the human remains and funerary attire, and identify infants' age, sex, and gender. Additionally, photographic documentation from the 1996, 2013, and 2014 inventories made by archaeologists from the University of Oulu was used to investigate the attire and coffin interiors. Details regarding the coffins, burial attire, and human remains of the CTscanned burials are presented in Table 2 .

The preservation of the CT-scanned coffins and human remains is varied. For example, the remains in Burials 10 and 22 are mummified, whereas the remains in Burials 20 and 21 are mainly skeletonized with some skin remains on the skull. The coffin of the newborn in Burial 21 is slightly broken in the area of the deceased's feet, and the lid is displaced. The acidic and moisture- 


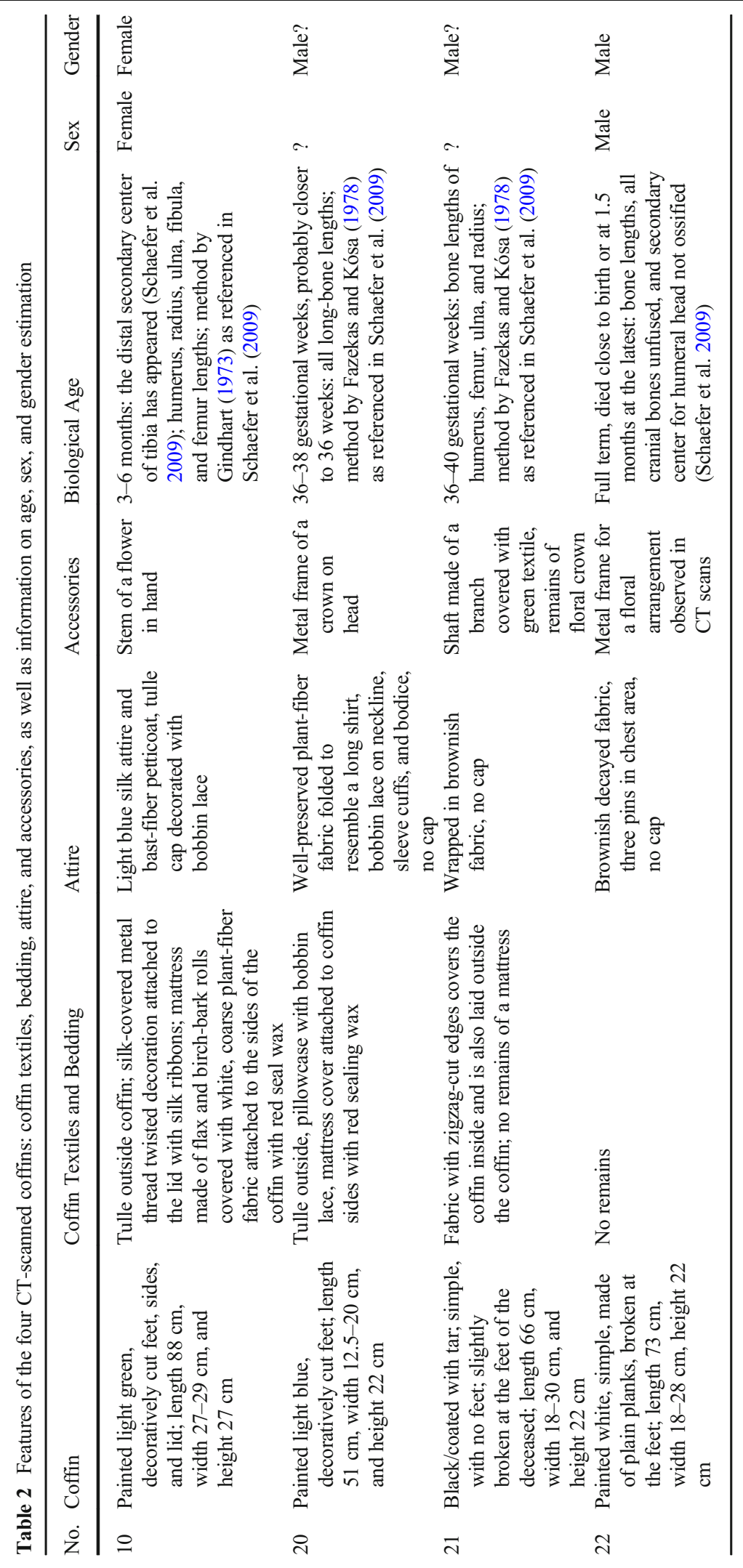


absorbing sand that has seeped into the coffin has caused the coffin bedding and funerary attire to deteriorate. The coffin lid in Burial 22 has never been opened, although the footboard is missing and the other boards are rotted, which permitted archaeologists to examine the interior (Fig. 4). The damage had occurred relatively recently, as in 1996 the coffin was described as intact, despite missing one front foot. Today the coffin has no feet. The newborn lies on a layer of sandy soil, and it is possible that all interior textiles have decayed.

The age of the human remains in the coffins was estimated based on several age-estimation methods represented by Schaefer et al. (2009). ${ }^{1}$ It should be noted that methods intended for fetal material (under 40 weeks) are not suitable for full-term children and vice versa. Fazekas and Kósa's (1978) age-estimation meth$\mathrm{od}^{2}$ (as represented in Schaefer et al. [2009]) was used when the child was younger than 40 weeks, while Gindhart's (1973) long-bone length age-estimation method $^{3}$ (as referenced in Schaefer et al. [2009]) was used when the child was full term or older. The general age range for the individuals in this study was estimated from ossification centers, after Fazekas and Kósa (1978) as represented in Schaefer et al. (2009). The observation of ossification centers is limited with CT imaging, as structures smaller than voxel size $(0.5 \times 0.6 \times 0.6 \mathrm{~mm})$ and adjacent structures of similar density cannot be separated in the image (Lipkin, Väre et al. 2018). Therefore, ossification centers - if smaller than voxel size and/or of similar density to cartilage - may not have been observable in the CT image and would result in younger age estimations based on the appearance of ossification centers. To prevent impacting age estimations should the ossification centers not be visible in the CT scans, children's age estimates were first narrowed

\footnotetext{
${ }^{1}$ Research by Schaefer et al. (2009) compiled studies of juvenile bioarchaeological research methods, incorporating major studies up to those publishing dates, such as Fazekas and Kósa (1978) and Gindhart (1973).

${ }^{2}$ Fazekas and Kósa (1978), as represented in Schaefer et al. (2009), provide age estimation based on ossification centers, dental development, and long-bone lengths from radiographic material of mid-20thcentury Hungarian fetal-autopsy remains.

${ }^{3}$ Gindhart's (1973) method, as presented in Schaefer et al. (2009), is based on white American children of European descent enrolled in the longitudinal program of the Fels Research Institute by mid-1967 (Schaefer et al. 2009). While the temporal and geographical origin of the population on which the methods are based are not fully equivalent to that of the population to which they are applied (which rarely is the case), the resultant age estimations should be within reasonable accuracy.
}

by utilizing long-bone lengths. The individual in Burial 20, for instance, died slightly preterm (not a full 40 weeks) at 36-38 weeks from gestation (2-4 weeks preterm). The individual in Burial 21 was between 4 weeks premature up to full-term (36-40 weeks from gestation). Burial 22 belonged to an individual who likely died near the time of birth, with a maximum age of 1.5 months, and the individual in Burial 10 was the oldest of the CT-scanned individuals, ca. 3-6 months of age (Table 2).

High Proportional Quantity of Very Preterm Infants, Newborns, and Infants in Keminmaa

In comparison to adult and older-child burials, the high proportion of newborn and infant burials at Keminmaa is distinctive. The CT-scanned burials indicate a clear correlation with the age of the infant and size of the coffin (Table 2). Even though the exact age of the newborns, infants, and children buried inside each unscanned coffin at St. Michael's Church at Keminmaa is unknown, it is likely that coffin size and age of the child are usually related. Approximately one-fourth of all child-sized coffins belong to infants and children who lived several months or years after birth; the rest of the coffins belong to newborns (Table 3). At Keminmaa, larger coffins have been recorded as belonging to adults or adult-sized individuals (15 examples, $25 \%$ ). The coffin sizes suggest that $53 \%$ of all individuals were preterm infants or newborns, which is a higher percentage of infants than Turpeinen (1979) identifies in Finland's national patterns of age at death (Table 1).

Any single mortuary sample like that at Keminmaa can only be suggestive of nationwide mortality patterns, and there is variation in the percentages of infants' and children's burials in individual Finnish cemeteries. For instance, at Oulu Cathedral's churchyard only ca. $17 \%$ of the excavated burials belong to children under three years of age (46 individuals of 266 burials) (Maijanen 2002; Sarkkinen and Kehusmaa 2002). It is possible that the infants in Oulu were buried outside the excavated areas at the churchyard, perhaps in a separate area for children. A similar feature in the funerary tradition seems to have occurred also in Keminmaa, where the under-floor space, from the mid-18th century onward, was preserved primarily for burials of infants of high status. Before the mid-18th century, adults were buried under floors more regularly than children (Paavola 1998:77-84, appendix 1), but during the 1750s and 
Fig. 4 The coffin of Burial 22 was broken at the footboards.

This image illustrates what was visible to archaeologists without CT scanning. Image is taken from the feet looking toward the head. (Photo by T. Väre, 2014.)

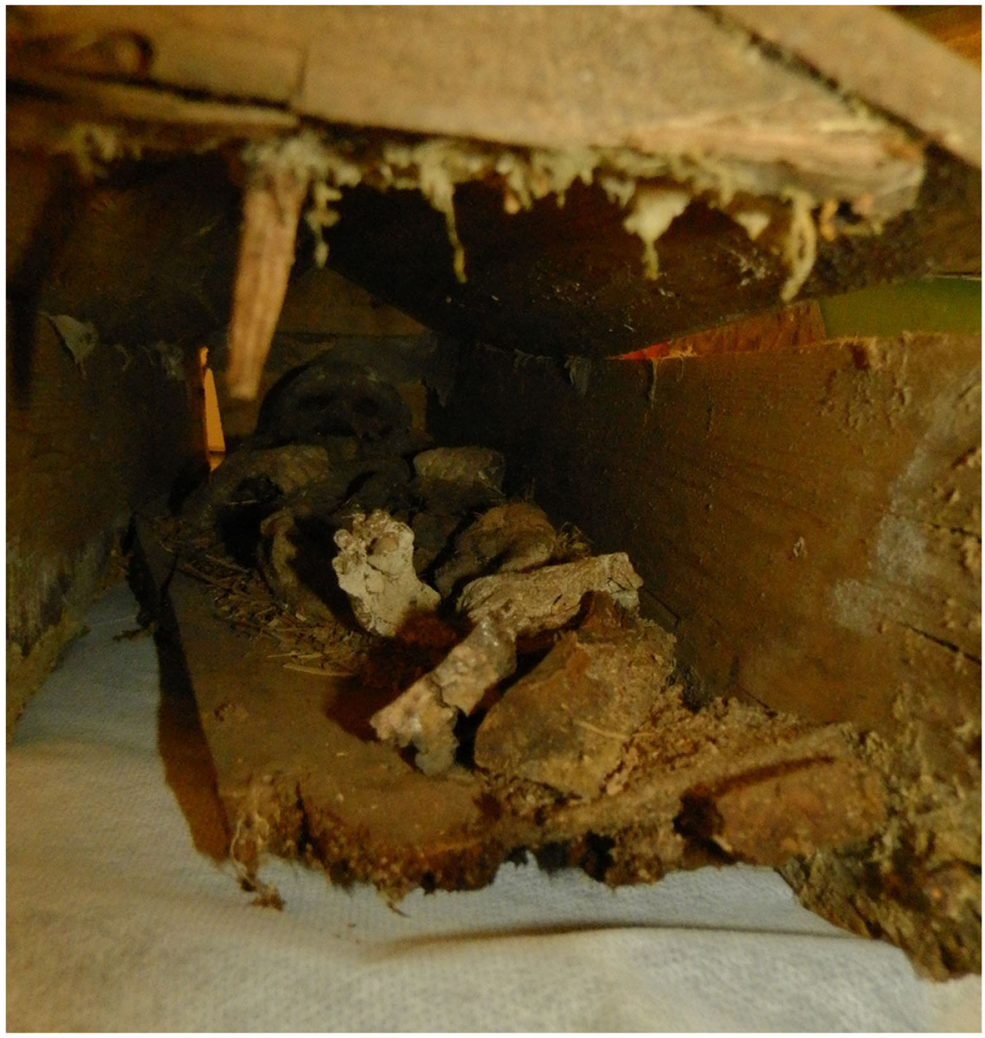

1760s almost all individuals buried inside the churches were clergymen's children, both in Keminmaa and throughout northern Ostrobothnia (Lipkin, KallioSeppä, and Väre 2018).

Based on coffin structures and the clothing on the deceased, the coffins currently under the floors in Keminmaa were predominantly laid there while the tradition of burial under church floors was becoming rarer (between the 1750s and 1760s) or after St. Michael's Church had been out of use for decades (between the late 1790s and the mid-19th century). After the 1790s, the old St. Michael's Church was abandoned and used mainly as a storage place for winter burials, which were laid on the floors, and, later in the spring, interred to the churchyard (Satokangas 1997:428).
Burial under the church floor continued on a limited basis, and, while a few adults were included, these later burials seem to be predominantly children. The fact that children's burials under the church floors persisted longer than those of adults may also indicate the ideas of purity and innocence that were commonly attached to children at the beginning of the modern era (Heywood 2013). During the late 18 th to early 19 th centuries, church burials were considered maleficent, and the permeating smells were considered disgusting, which led to abandonment of the custom (Kallio-Seppä and Tranberg, this issue). As children produce less unpleasant odor than adults (Giles 2013:476), it was probably easier to justify their burial under the floors for a longer period of time.

Table 3 Lengths of prematurely born, newborn, infant, and child coffins in Keminmaa, and suggested associated age categories

\begin{tabular}{|c|c|c|c|c|c|c|c|}
\hline & No Coffin & $20-41 \mathrm{~cm}$ & $51-64 \mathrm{~cm}$ & $65-78 \mathrm{~cm}$ & $80-89 \mathrm{~cm}$ & $97-115 \mathrm{~cm}$ & Total \\
\hline No. of Coffins & 1 & 2 & 8 & 23 & 6 & 4 & 44 \\
\hline Possible Age Category & - & Preterm & Newborn & Newborn/ infant & Infant & Child & - \\
\hline
\end{tabular}

Note: Age categories were created based on the known coffin lengths and the ages of the four CT-scanned individuals studied in this article. 
The sanctity of the old building was also likely important for the families who buried their young children under the floors of an abandoned church. This is further highlighted by the presence of infants clearly prematurely born or miscarried buried in small coffins or cases made from thin boards similar to roof shingles. Their presence suggests that baptism was not a prerequisite to burial under the church floor. One of the smallest, prematurely born mummified individuals is only $12 \mathrm{~cm}$ long and was found without any coffin (Ojanlatva and Paavola 1997). Based on the extremely small size, this individual was a miscarriage. Similar cases have also been found in other Finnish and Swedish churches (Suvanto 2005; Hagberg 2006:518), and, according to Emil Nervander (1896:584), in Keminmaa a number of cases were originally laid next to the remains of Vicar Nikolaus Rungius. Even though these cases have since disappeared from the church, their proximity to a famous clergyman suggests that the very early preterm infants were valued by their communities (Lipkin, Kallio-Seppä, and Väre 2018:72-76).

Care and Dedication toward Newborns and Infants

Religious traditions suggest that newborns and prematurely born infants held an inferior status in 17th-century Swedish society (Rimpiläinen 1971:268-275; Itkonen 2012:13-15), but archaeological material from 18th- to 19th-century Keminmaa and elsewhere in northern Ostrobothnia suggests the contrary. Research indicates that children, especially infants and the youngest children, received considerably more elaborate funerary accessories, including silk slippers, christening belts, caps, and floral decorations, than their older counterparts (Lipkin and Kuokkanen 2014:44; Lipkin, Vajanto et al. 2015). The coffins and attire at Keminmaa show clear signs of care and dedication. These children were socially valued in life, and dead children were mourned. Although the newborns considered here were either born dead or died shortly thereafter, both historical sources and burial customs indicate that their births were expected and their deaths grieved. Their coffins are made of painted (blue, green, white, black) boards, and some of the coffin feet are cut in a particularly decorative style (Table 2). The coffins are of the right size for the infants, and their manufacture and decoration required increased level of effort and investment, which indicate that these infants were valued and mourned. Their burials were worthy of decoration. The fabrics chosen to cover and decorate the coffins are usually made from plant fibers and are white and simple, but decorated with tulle or trimmed with zigzag-cut edges that are also visible on the exterior. The fabrics for covering the coffin bedding, as well as constructing the attire, were repurposed old textiles, such as sheets or curtains. The funerary material throughout northern Ostrobothnia proves that the funerary attire was not real clothing, but fabrics folded around the deceased to resemble real clothing and sewn together with rough stiches or attached with pins. For instance, in Keminmaa, the CT scan of Burial 22 shows three pins attached to the chest area (Fig. 5).

Due to high child mortality, families developed a number of coping mechanisms to deal with the loss of their youngest loved ones. The ritual of youths making funerary clothes for children, as described previously (Wacklin 1844:2,21), is a testimony to people looking to the future. Families comforted themselves by acknowledging the difficulty of life. A child's death could be considered as a relief, particularly if the child had been ill before death. Wacklin $(1844: 1,2)$ provides one textual example of a grieving mother: "By the coffin of her

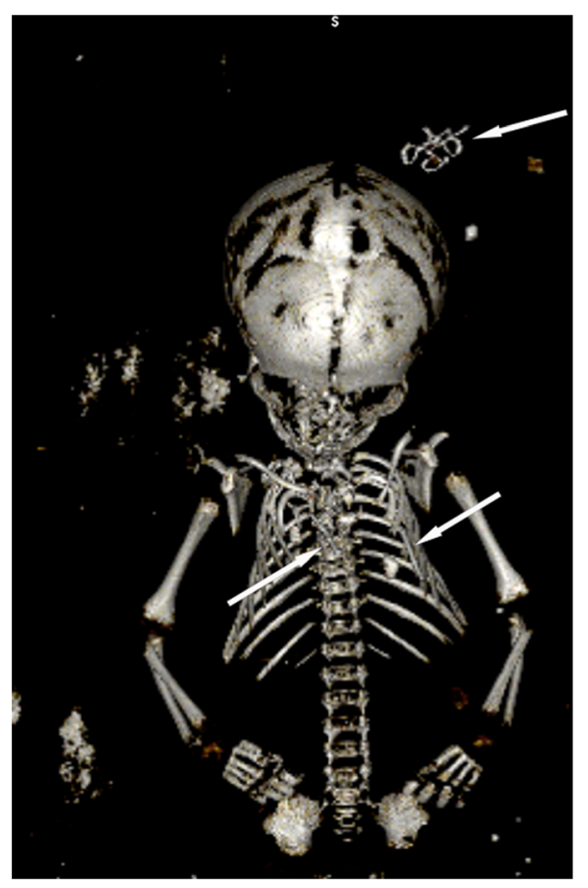

Fig. 5 Burial 22, Keminmaa: A frame for a floral arrangement was discovered in the CT-scan images. Three pins are also seen above the spine and ribs. (Reconstructed $\mathrm{CT}$ image by $\mathrm{S}$. Niinimäki, 2017.) 
dead child she represses her pain and thanks God, who had mercy to take the child away from this miserable land." Old lullabies (from "Kanteletar," a collection of old Finnish poems gathered during the 19th century) described a child's grave as a peaceful place, further suggesting that high child mortality impacted the way childhood was perceived (Achté et al. 1987). These practices may have been a way for a mother to prepare for the possibility of an early death, to mourn before the child even died, and to introduce the possibility of a child's death to peers. As children's deaths were something to be expected, it was better to be prepared beforehand. Many families lost their children, especially in times of distress, such as years of crop failures and disease (e.g., during the Famine of 1868 and the Finnish War of 1808) (Table 1).

\section{Innocence and Gender Roles}

The coffin was furnished as a bed on which the deceased slept while awaiting the resurrection of the dead (Hagberg 2006:220). Because Wacklin's (1844:2,21) story “Clothing for the deceased" has clear analogies in the burials in Keminmaa, it is relevant to discuss her account and the burials side by side. Wacklin's description includes symbolism of purity that, from the beginning of the 18th century, was attached to childhood. Purity and virginity are represented through the infants' white clothing. In addition, the organizer's identity, that of the virgin godmother, also implies the importance of purity in the provider of clothing for young dead children. Similarly, Wacklin $(1844: 2,21)$ describes that, in the 19th century, it was a practice to bury girls "in a cloud/sky," with either sky-blue or white fabrics (Hagberg 2006:203). This implies the heavenly connotation by the appearance of children's clothing, especially in Burial 10 at Keminmaa, which, based on soft tissues, belongs to a female infant. In this burial, tulle fabric, typical of the mid-19th century (Marks 1959:569), covers the infant as if she were sleeping below an ethereal blanket. This tulle also hangs outside the decoratively cut coffin and has small silk or paper flowers attached with pins (Fig. 6). The infant is covered with a mid-19th-century (Ciszuk 2012:40-51) light blue silk fabric that is folded to resemble a female

\footnotetext{
${ }^{4}$ In Swedish: "sveptes liksom i en sky av kammarduk eller annat fint hvitt tyg" (wrapped as if in a cloud of fine linen or other fine white cloth).
}

dress (Fig. 7). The sleeves are folded from this same fabric and roughly sewn in cuffs. All decorative elements in the cuffs, tulle cap, and pillowcase of the ensemble are made with bobbin lace and wide satin tape.

It is likely that individuals in Burials 21 and 22 were originally wrapped in white fabrics similar to those in Burial 20, but soil contact has caused them to decay and turned them brownish. In Burial 20, the attire is made from white fabrics, and tulle fabric circles the coffin edge. The fabrics covering the human remains are folded to resemble a long undershirt, and the bodice, sleeve cuffs, neckline, and pillowcase have been decorated with various bobbin laces (Fig. 8). The newborn does not wear a cap, but wears a copper-alloy-based crown with textile leaves on the head. The sex of the individual could not be identified, but the type of shirt and lack of a cap or flower sprig in hand may indicate that the burial belonged to a male newborn. In Finnish postmedieval burials, flower sprigs are typically placed with girls, while the lack of caps and shirt bodices with vertical lace is securely associated with burials of infant or child boys.

The different styles of attire for girls and boys proves that socialization through enculturation was extended even to the burial. Generally, the northern Ostrobothnian materials indicate that children were culturally "gendered" from birth. While girls' dresses resembled those of adult women, boys' clothes mimicked those of adult men. A similar gender-based pattern is seen among caps worn in life and not crafted for burial; ethnographic museum collections from the 18th and 19th centuries indicate that boys wore a wedged christening cap, while girls wore a "heart" christening cap (Lehtinen and Sihvo 2005:102-103). A similar gender division is noted also in archaeological material that has been studied in detail. Adult males have either corduroy, bast-fiber, or wedgedwool caps, and similar caps have been found in infant burials. Some infant/small-child burials identified or interpreted as belonging to boys have no caps. Likewise, "heart" caps are also archaeologically supported by girls' burials, in addition to simple silk, tulle, or bast-fiber caps.

Boys' floral rods and crowns, also mentioned by Wacklin (1844:2,21), were considered symbols of manhood that were needed during the journey to heaven (Hagberg 2006:202-210). At Keminmaa, a rod cut into two pieces and made of a branch covered with greenish textile lies on the abdomen of the individual in Burial 21 (Fig. 9). On the left side of the head the infant has fragments of a floral crown made of bronze-alloy wire 
Fig. 6 Small paper flowers were attached to tulle fabric that decorated the coffin edges of Burial 10, Keminmaa. This type of bobbinet tulle was manufactured beginning in 1809 (Marks 1959:569). (Photo by S. Lipkin, 2014.)

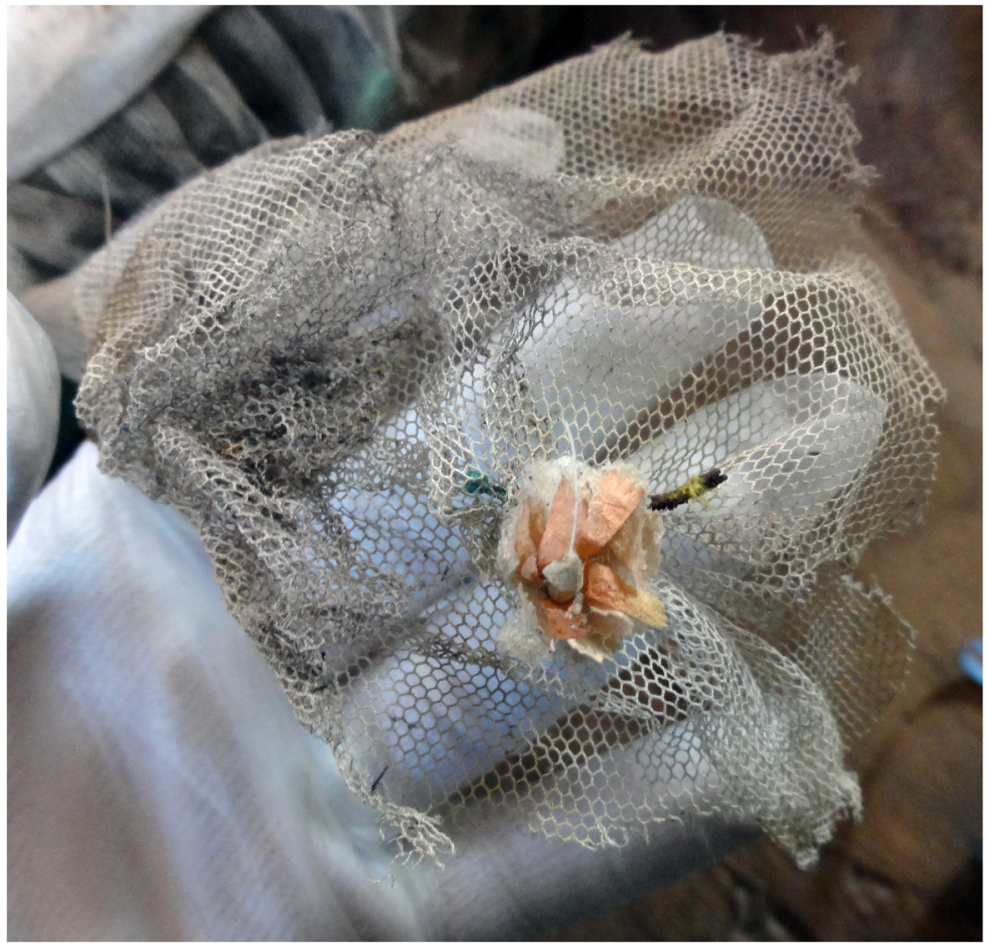

Nineteenth-century ethnographic evidence suggests that bridal crowns and bouquets were placed on the heads and in the hands of unmarried girls, and that they were occasionally dressed as brides. They had not lived long enough to receive bridal crowns in earthly life, but were provided with "life's crowns" in burial. To express the children's innocence, virginity, and status as
Fig. 7 Burial 10, Keminmaa: An infant buried in a blue silk garment folded to resemble a female dress. The cuff is hastily sewn. (Photo by S. Lipkin, 2014.)

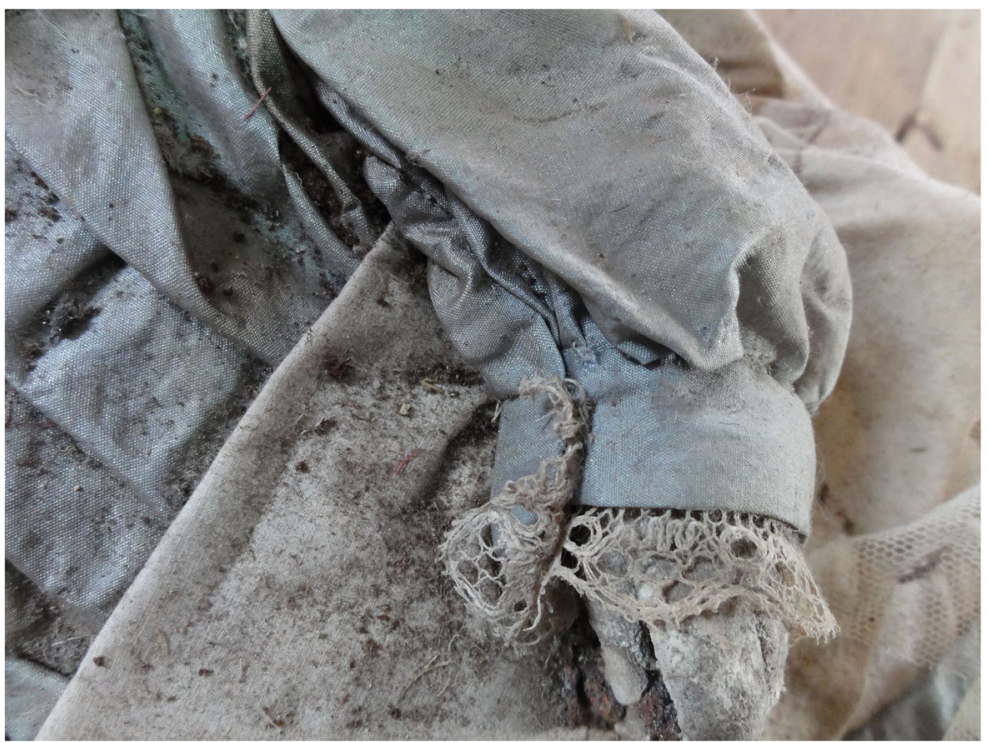




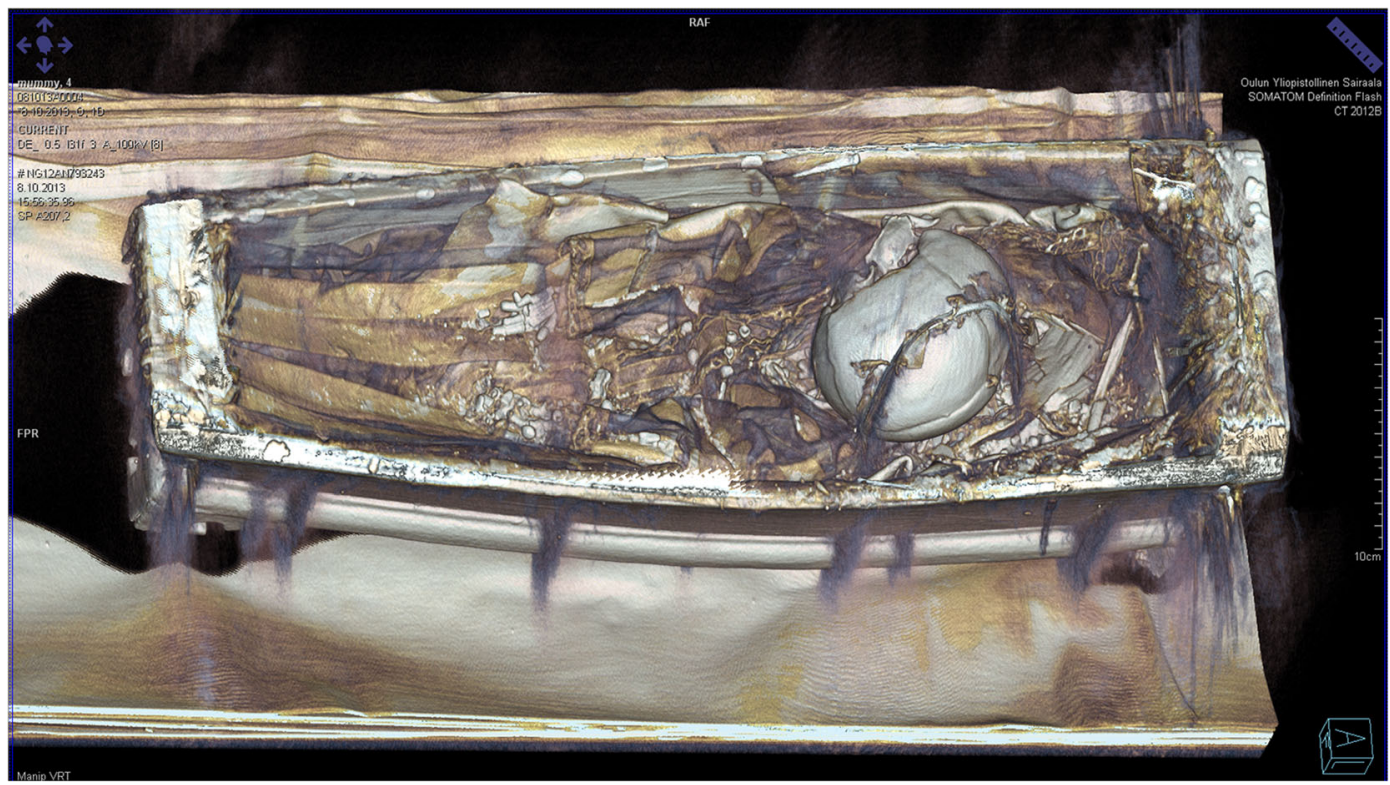

Fig. 8 Skeletonized infant remains in Burial 20 were covered with neatly folded fabric decorated with laces. The deceased wears a metalbased floral wreath on the head. (Reconstructed CT image by J. Niinimäki, 2014.)

heavenly queens, a crown was a symbol of a "Bride of Christ." This tradition of burying unmarried girls as brides and boys as grooms seems to be a transEuropean practice, with roots in the 16th century (Hagberg 2006:202-210). As shown in the associated CT scan, the infant in Burial 10 holds the metal stem of the floral decoration in her hand, although the flowers themselves have decayed (Fig. 10). Furthermore, it is possible that the metal and silk-thread item attached to the lid of Burial 10 at Keminmaa is a bridal crown (Fig. 11). Such a crown has also been recorded on a newborn's coffin in Sura, Sweden (Jonsson 2009:137). It is noteworthy that the general appearance of the burials from Keminmaa does not differ from those in Sweden, and both Nyberg (2010) and Jonsson (2009:146) consider that it was likely that young girls were dressed as brides. CT scanning has offered the possibility of examining the sex of the infants based on soft tissues, and, in some cases, the epitaphs in the coffins reveal the genders of northern Ostrobothnian children. An examination of sex and gender in these burials indicates that the combination of wreaths in
Fig. 9 Burial 21, Keminmaa: Brownish fabric is folded around the infant. Remains of a metalbased wreath were found beside the head, and a wooden rod with a greenish textile lies above the abdomen. (Reconstructed CT image by S. Niinimäki, 2017.)

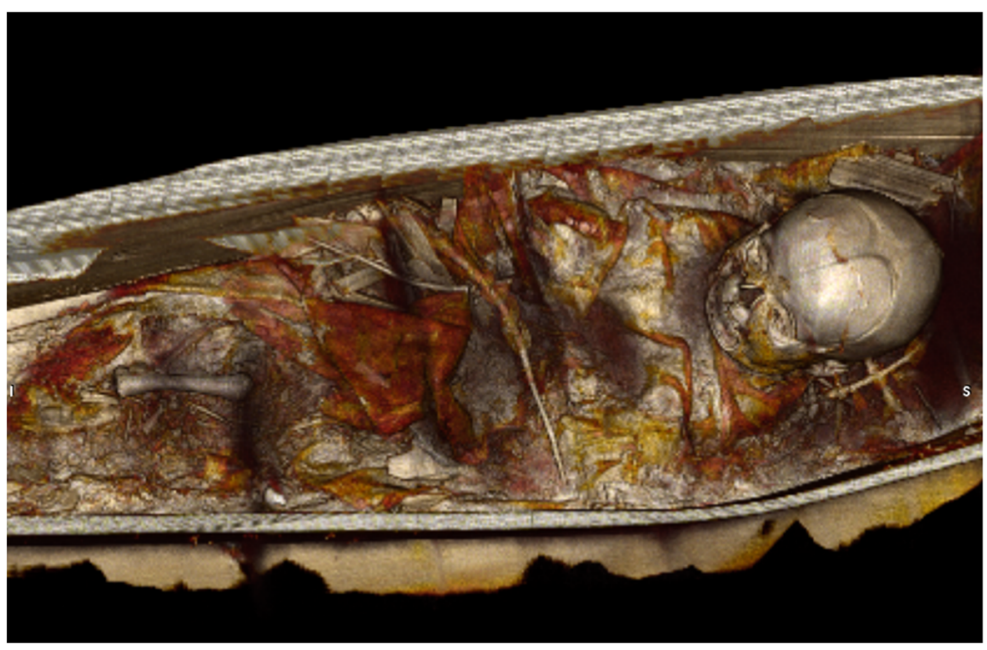




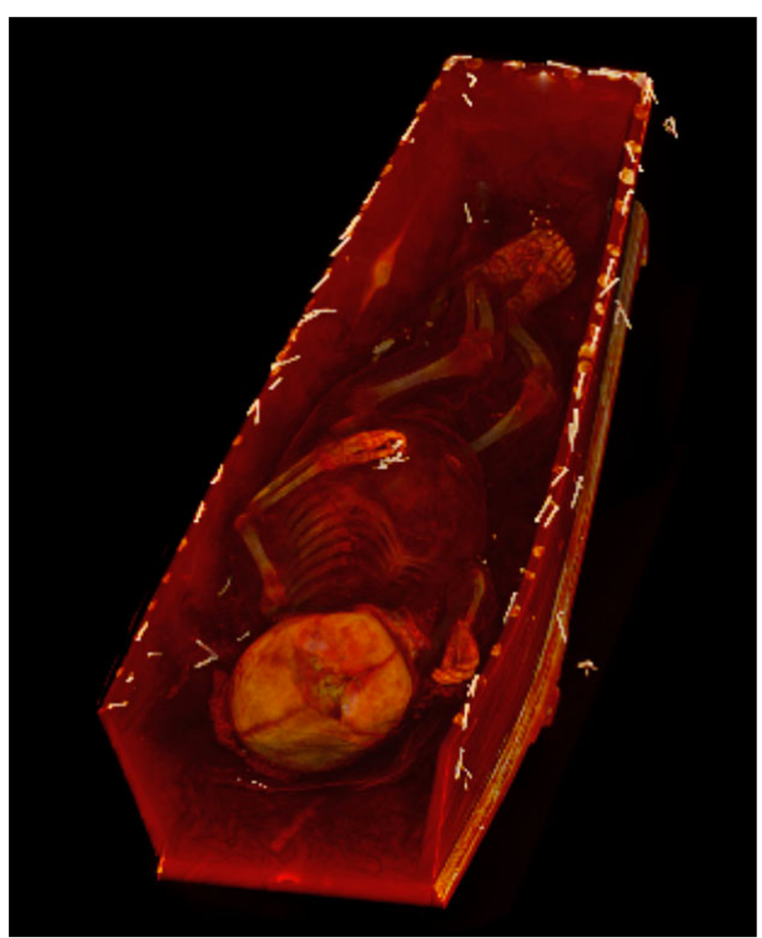

Fig. 10 The infant in Burial 10 holds the metal stem of an artificial flower in her hand. Red sealing wax and pins are also visible in the CT-scan image. (Reconstructed CT image by $\mathrm{S}$. Niinimäki, 2017.)

hands and wreath crowns on heads was not reserved for girls only, which is contrary to Nyberg's (2010:24) assumption. In northern Ostrobothnia, green silk flower wreaths were crafted for both boys and girls. The only difference between the two genders is that a girl was

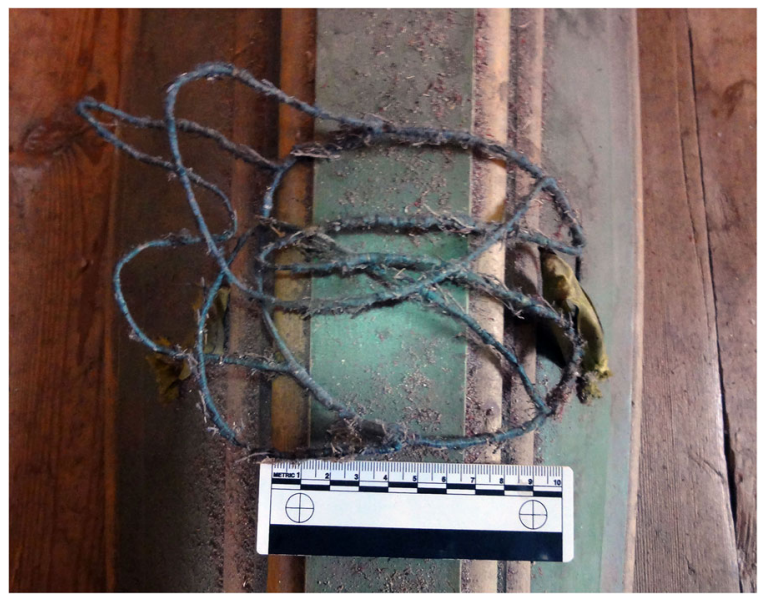

Fig. 11 Keminmaa, Burial 10: This flattened metal-based decoration found on the coffin lid may have originally been a crown. It was attached to the lid with green silk fabric. (Photo by S. Lipkin, 2014.) usually buried with a flower stem in her hand, whereas a boy, if not buried with a rod, holds in his hand a wreath consisting of multiple flowers and leaves. Similarly constructed wreaths are placed on the chests of both boys and girls.

It is difficult to estimate at what age the burial of children as brides and grooms began, but the children in the Swedish archival and ethnographic examples provided by Hagberg (2006:202-210) were at least one year old, and in many recorded cases the children were, in fact, older. In the northern Ostrobothnian archaeological material, no clear difference is seen between infantand child-burial accessories. The practice of making floral arrangements began in the 17th century and persisted until the early 19th century in adolescent and young-adult burials, including also at least one male burial in Oulu (Maijanen 2002; Sarkkinen and Kehusmaa 2002).

Becoming a bride and tying wreaths for children are also contextualized by Wacklin $(1844: 2,21)$. She refers to children's burial wreaths and bridal wreaths in the same sentence: "Laughing they tied the death wreath, and often the result was that soon thereafter a bridal wreath was tied." Although Wacklin does not refer to death and bridal wreaths as equal, the textual context of combining the two is clear. It is possible that some children were buried as brides or grooms. Newborns were more likely buried in their christening clothes or attire that resembles christening clothes. In Ostrobothnian burials, many silk christening caps and swaddling belts have been identified archaeologically and are similar in materials and style to the Swedish christening gowns and caps in Stockholm's Nordiska museet collections (DigitaltMuseum 2020). Many of the northern Ostrobothnian archaeological caps were possibly used in christening a newborn in life, although some families may not have been able to afford to or chose not to inter their children with valuable christening caps, as they were usually made from silk and decorated with silver-thread embroidery and laces. The caps could also be items that were passed down from one generation to the next. This may explain why some caps in northern Ostrobothnia were crafted from pieces of secondhand fabric. More often the newborns and infants in both Keminmaa and northern Ostrobothnia at large were dressed in clothes roughly sewn or pinned together. Even though repurposed and unfashionable precious materials (such as silks, laces, and silver-thread embroidery) were used to construct the attire, these are not christening 
gowns, and it is impossible to know whether all the individuals in question were baptized before their deaths.

\section{Ostrobothnian Female Adolescents as Children's Funerary-Attire Makers}

In the area of northern Ostrobothia the number of unearthed and reported adolescent burials is very small. For example, at Oulu Cathedral only three burials belonging to individuals between 12 and 20 years of age have been recorded, and these do not seemingly differ from those of adults (altogether 151 burials have been identified as belonging to adults [Maijanen 2002; Sarkkinen and Kehusmaa 2002]). The adolescents and their role in the funerary rites pertaining to children are addressed here through Wacklin's writings and existing infant burials, rather than through adolescent burials. The adolescents, now preparing for their own marriages, were almost children themselves, but they were, according to Wacklin (1844:2,21), still responsible for providing clothing for young dead children. It is possible that the custom of burial preparations was one form of active socialization initiated by adults. Firstly, to offer a coping mechanism for the youth in the face of a child's death, and, secondly, this practice allowed the youth to reproduce the gender roles of the society. The youth who were trusted to become godmothers were also considered to be old enough to face the realities of life and be capable of providing suitable clothing for dead children. Wacklin's writing offers an avenue to understand youths' perceptions of children's deaths. Even though these youths had already themselves been socialized to the world around them, their perceptions concerning infancy and death may have been different from those of their parents.

The challenge here is to differentiate between the voices of the youth and those of the adults; one cannot be sure which funerary attire was produced by the youth and which was not. If much of the funerary attire seen in the archaeological material was made by the youth, one may interpret that the youth actually reproduced gender roles through making different kinds of funerary clothes for boys and girls, and throughout the decades these gender roles seem to remain more or less stable. For instance, five mid-18th-century burials from Haukipudas reflect gendered clothing patterns similar to the late 18th-century to mid-19th-century burials from Keminmaa presented in this article.
Nevertheless, the occasion of youths making funerary attire for children described by Wacklin $(1844: 2,21)$ may be interpreted as a way to deal with the emotions that arose when children died young (Lipkin, KallioSeppa, and Ylimanu 2017). On these occasions, as Wacklin describes $(1844: 2,21)$ : "No-one thought of death." Laughing, chatting, and crafting would have made the occasion more relaxed and may have made it easier for youths to understand the deaths of their younger siblings, godchildren, and their own future children.

\section{Conclusions}

High child mortality clearly affected how infancy and early childhood were perceived and how infancy and adolescence were culturally constructed in late 18th- to early 19th-century Finland. The research indicates that prematurely born or stillborn children, newborns, and infants were socially valued in life and mourned in death; burials in the case study from Keminmaa indicate both care and dedication. Most of the deceased in Keminmaa seem to be newborns of the upper social classes, and merely the fact that they were buried under the church floor proves that they were valued in the eyes of the community. Burial practices and Wacklin's writing indicate innocence, purity, and socialization according to both gender and family status. Historical sources imply that there are blurring lines between "childhood" and "adulthood," and it seems that the preparation for infant burial gave the adolescents a glance at future adulthood without fully entering it. The youth were socialized into their future roles as parents who were expected to lose their children; and they reproduced social gender roles while crafting burial dress and accessories for their godchildren.

Acknowledgments: This article was written as part of the activities of Sanna Lipkin's Academy of Finland Project: "New Perspectives on Childhood in Finland (1600-1900): Funerary Attire as an Indicator of Status of Children." We would also like to thank fellow researchers of the Church, Space and Memory Project funded by the Emil Aaltonen Foundation.

Funding Open access funding provided by University of Oulu including Oulu University Hospital.

\section{Compliance with ethical standards}

Conflict of Interest Statement On behalf of all the authors, the corresponding author states that there is no conflict of interest. 
Open Access This article is licensed under a Creative Commons Attribution 4.0 International License, which permits use, sharing, adaptation, distribution and reproduction in any medium or format, as long as you give appropriate credit to the original author(s) and the source, provide a link to the Creative Commons licence, and indicate if changes were made. The images or other third party material in this article are included in the article's Creative Commons licence, unless indicated otherwise in a credit line to the material. If material is not included in the article's Creative Commons licence and your intended use is not permitted by statutory regulation or exceeds the permitted use, you will need to obtain permission directly from the copyright holder. To view a copy of this licence, visit http://creativecommons.org/licenses/by/4.0/.

\section{References}

Achté, Kalle, Juha Pentikäinen, and Ritva Fagerström

1987 Tuutilasta Tuonelaan-Kuoleman ja väkivallan teemat eri maiden kehtolauluissa (Lull a child to the afterlife - themes of death and violence in lullabies from different countries). Suomen Antropologi 12(1):20-26.

Becker, Marshall Joseph

2004 The Cazzanello Perinatal Cemetery: Continuities of Etruscan Mortuary Practices into the Late Antique Period and beyond. Studi Etruschi 70:255-267.

Ciszuk, Martin

2012 Silk-Weaving in Sweden during the 19th century. Textiles and Texts - an Evaluation of the Source Material. Thesis for the degree of Licentiate of Philosophy, Department of Product and Production Development, Chalmers University of Technology, Gothenburg, Sweden.

DigitaltMuseum

2020 Dräkt: dopkläder: doppåsar (Clothes: Christening clothes: Christening gowns). DigitaltMuseum $<$ https://digitaltmuseum.se/search/?aq=topic $\% 3$ A\%22Dr\%C3\%A4kt\%20\%3A\%20Dopk1\%C3 \%A4der\%20\%3A\%20Dopp\%C3\%A5sar\%22 $\& o=0 \& n=176>$. Accessed 20 August 2020.

Fazekas, István Gyula, and F. Kósa

1978 Forensic Fetal Osteology. Akadémiai Kiadó, Budapest, Hungary.

Giles, Melanie

2013 Preserving the Body. In The Oxford Handbook of the Archaeology of Death and Burial, Sarah Tarlow and Liv Nilsson Stutz, editors, pp. 475-496. Oxford University Press, Oxford, UK.

Gindhart, Patricia S.

1973 Growth Standards for the Tibia and Radius in Children Aged One Month through Eighteen Years. American Journal of Physical Anthropology 39(1):41-48.

Hagberg, Louise

2006 När döden gästar. Svenska folkseder och svensk folktro i samband med död och begravning (When death visits: Swedish folktales and Swedish folk beliefs in connection with death and burial). Wahlström \& Widstrand, Stockholm, Sweden.

Halila, Aimo

1953 Oulun kaupungin historia II 1721-1809 (History of the town of Oulu II 1721-1809). Kirjola Oy, Oulu, Finland.

Halila, Aimo

1954 Pohjois-Pohjanmaan ja Lapin historia V (History of northern Ostrobothnia and Lapland V). Kalevan Kirjapaino, Oulu, Finland.

Heywood, Colin

2013 A History of Childhood: Children and Childhood in the West from Medieval to Modern Times. Polity, Cambridge, UK.

Hiekkanen, Markus

2014 Suomen keskiajan kivikirkot (Medieval churches in Finland). Suomalaisen Kirjallisuuden Seura, Helsinki, Finland.

Itkonen, Juha

2012 Kuolleena syntynyt lapsi Suomen evankelisluterilaisen kirkon kirkkokäsikirjoissa 16942003 (Stillborn children in the church manuals of the Evangelical Lutheran Church of Finland 1694-2003). Thanatos 1(2). Thanatos <https://thanatosjournal.files.wordpress .com/2012/12/itkonen_kuolleena-syntynyt-lapsi1.pdfs. Accessed 15 May 2019.

Jonsson, Kristina

2009 Practices for the Living and the Dead. Medieval and Post-Reformation Burials in Scandinavia. Stockholm University, Stockholm Studies in Archaeology 50. Stockholm, Sweden.

Junnila, Olavi

1987 Autonomian rakentamisen ja kansallisen nousun aika (Building autonomy and era of the rise of the nation). In Suomen Historia 5, 2nd edition, Paula Avikainen and Erkki Pärssinen, editors, pp. 11167. Weilin \& Göös, Espoo, Finland.

Lehtinen, Ildikó, and Pirkko Sihvo

2005 Rahwaan puku-Folk Costume. Museovirasto, Helsinki, Finland.

\section{Lillehammer, Grete}

2010 Introduction to Socialisation: Recent Research on Childhood and the Children in the Past. In Socialisation: Recent Research on Childhood and the Children in the Past, Grete Lillehammer, editor, pp. 9-19. University of Stavanger, Museum of Archaeology, Stavanger, Norway.

Lipkin, Sanna, Titta Kallio-Seppä, and Tiina Väre

2018 Pappissäädyn haudat Pohjois-Pohjanmaan kirkkojen lattioiden alla-Tapaustutkimuksia 1300-1700-luvuilta (Clergy burials under northern Ostrobothnian churches - case studies from the 14th to the 18th centuries). Thanatos 7(2):60-86. Thanatos <https://thanatosjournal.files.wordpress .com/2019/01/lipkin_vare_kallio-seppa_pappissaadyn .pdf>. Accessed 10 February 2019.

Lipkin, Sanna, Titta Kallio-Seppä, and Timo Ylimaunu

2017 Muisti ja tunteet — näkökulma pohjoissuomalaisiin kirkkohautaustapoihin (Memory and emotions-a 
perspective on northern Finnish church-burial traditions). Muinaistutkija 2017(2):14-22.

Lipkin, Sanna, and Tiina Kuokkanen

2014 Man Buried in His Everyday Clothes-Dress and Social Status in Early Modern Oulu. In Focus on Archaeological Textiles: Multidisclipinary Approaches, Sanna Lipkin and Krista Vajanto, editors, pp. 40-53. Monographs of the Archaeological Society of Finland 3. Helsinki, Finland. Suomen Arkeologinen Seura <http://www .sarks.fi/masf/masf_3/MASF3_03_Lipkin_Kuokkanen.pdf \$. Accessed 29 July 2020.

Lipkin, Sanna, Krista Vajanto, Titta Kallio-Seppä, Tiina Kuokkanen, Sirpa Niinimäki, Tiina Väre, and Martin van Bommel

2015 Funeral Dress and Textiles in 17th and 19th Century Burials in Ostrobothnia, Finland. In Aspects of the Design, Production and Use of Textiles and Clothing from the Bronze Age to the Early Modern Era. NESAT XII. The North European Symposium of Archaeological Textiles 21st-24th May 2014 in Hallstatt, Austria, Karin Grömer and Frances Pritchard, editors, pp. 209221. Budapest, Hungary.

Lipkin, Sanna, Tiina Väre, Titta Kallio-Seppä, Annemari Tranberg, Erika Ruhl, Sirpa Niinimäki, Juho-Antti Junno, Mikko Finnilä, and Jaakko Niinimäki

2018 Benefits of CT-Scanning in Study of Post-Medieval Funerary Items. Poster presented at meeting of the Society for American Archaeology, Washington DC.

Maijanen, Heli

2002 Luumääritykset (Osteological report). In Oulun tuomiokirkon kirkkotarhasta, Mika Sarkkinen and Aimo Kehusmaa, authors, Appendix 1. Manuscript, Northern Ostrobothnia Museum, Oulu, Finland.

Mäntylä, Ilkka

1997 Suurvaltakausi, Vapauden aika (The superpower age, the age of liberty). In Suomen historian pikkujättiläinen, 7th edition, Seppo Zetterberg, editor, pp. 181-311. WSOY, Porvoo, Finland.

Marks, Stephen S. (editor)

1959 Fairchild's Dictionary of Textiles. Fairchild, New York, NY.

Nervander, Emil

1896 Taidehistoriallisen retkikunnan retkipäiväkirja 1896 (Excursion diary of the art-historical expedition 1896). Museovirasto, Suomen Muinaismuistoy hdistyksen arkisto, Helsinki, Finland

Nyberg, Jenny

2010 A Peaceful Sleep and Heavenly Celebration for the Pure and Innocent: The Sensory Experience of Death during the Long Eighteenth Century. In Making Sense of Things: Archaeologies of Sensory Perception, Fredrik Fahlander and Anna Kjellström, editors, pp. 15-33. Stockholm University, Department of Archaeology and Classical History, Stockholm, Sweden.

Ojanlatva, Eija, and Kirsti Paavola (editors)

1997 Keminmaan kirkkohaudat (Church burials from Keminmaa). Meteli, Oulun yliopiston arkeologian laboratorion tutkimusraportti 14. Oulu, Finland.
Oulun maakunta-arkisto (OMA)

1751-1802 Syntyneiden, avioituneiden ja kuolleiden luettelot (List of the born, married, and dead). IK3, IA1:2, Tervolan seurakunnan arkisto, Oulun maakunta-arkisto, Oulu, Finland.

Oulun maakunta-arkisto (OMA)

1758-1812 Kuolleiden ja haudattujen luettelot (List of the dead and buried). MKO58-59, I Eb:1, Hailuodon seurakunnan arkisto, Oulun maakunta-arkisto, Oulu, Finland.

Oulun maakunta-arkisto (OMA)

1779-1814 Kuolleiden ja haudattujen luettelot (List of the dead and buried). IC:3, IK227, Tervolan seurakunnan arkisto, Oulun maakunta-arkisto, Oulu, Finland.

Oulun maakunta-arkisto (OMA)

1803-1866 Kuolleiden luettelot (List of the buried). IC: 1, Kempeleen seurakunnan arkisto, Oulun maakunta-arkisto, Oulu, Finland.

Paavola, Kirsti

1998 Kepeät mullat. Kirjallisïn ja esineellisïn lähteisïn perustuva tutkimus Pohjois-Pohjanmaan rannikon kirkkohaudoista (Light soils. A study of church burials on the coast of northern Ostrobothnia based on written and material sources). Acta Universitatis Ouluensis B Humaniora 28. Oulu, Finland.

Rimpiläinen, Olavi

1971 Läntisen perinteen mukainen hautauskäytäntö Suomessa ennen isovihaa (The Western tradition of burials in Finland before the Great Northern War). Suomen Kirkkohistoriallinen Seura, Helsinki, Finland.

Sarkkinen, Mika, and Aimo Kehusmaa

2002 Oulun tuomiokirkon kirkkotarhasta (About Oulu Cathedral cemetery). Manuscript, Northern Ostrobothnia Museum, Oulu, Finland.

Satokangas, Reija

1997 Murroksen aika (1860-1930) (Time for changes [1860-1930]). In Keminmaan historia, Pentti Koivunen, Jouko Vahtola, Reija Satokangas, and Martti Itkonen, editors, pp. 250-443. Keminmaan kunta, Keminmaan, Finland.

Schaefer, Maureen, Sue Black, and Louise Scheuer

2009 Juvenile Osteology. A Laboratory and Field Manual. Academic Press, Amsterdam, the Netherlands.

Seppälä, Jarkko

1998 Rippikoulun ja konfirmaation kehitys (Development of Confirmation School and Confirmation). In Kartalla. Rippikoulutyön käsikirja, Antero Rissanen, editor, pp. 15-79. Kirkon kasvatusasiain keskus, Helsinki, Finland.

Suvanto, Maria

2005 Tornio, Tornion kirkko. Alapohjan kunnostustöiden arkeologinen valvonta 1.9.-14.10.2005 (Tornio, Tornio church. Archaeological monitoring 1.9.14.10.2005). Manuscript, Museovirasto, Helsinki, Finland.

Turpeinen, Oiva

1979 Fertility and Mortality in Finland since 1750. Population Studies 33(1):101-104. 


\section{Vainio-Korhonen, Kirsi}

2012 Ujostelemattomat. Kätilöiden, synnytysten ja arjen historiaa (Unabashed. History of midwives, childbirth, and everyday life). WSOY, Helsinki, Finland.
Wacklin, Sara

1844 Hundrade Minnen från Österbotten (A hundred memories from Ostrobothnia), Vols. 1-2. K. R. Looströms bokhandel, Stockholm, Sweden.

Publisher's Note Springer Nature remains neutral with regard to jurisdictional claims in published maps and institutional affiliations. 